\title{
COMPARATIVE EFFICIENCY ANALYSIS OF CONVENTIONAL BANKS AND ISLAMIC BANKS: IN EVIDENCE OF PAKISTAN
}

\author{
Khalid Mehmood ${ }^{1}$, Natalja Lace ${ }^{2}$, Irena Danilevičiené $\dot{\mathbf{3}}^{\mathbf{3}}$ \\ ${ }^{1,2}$ Faculty of Engineering Economics and Management, Riga Technical University, \\ Kalnciema Str. 6, LV-1048, Riga, Latvia \\ ${ }^{3}$ Department of Finance Engineering, Faculty of Business Management, \\ Vilnius Gediminas Technical University, Saulètekio al. 11, LT-10223, Vilnius, Lithuania \\ E-mails: ${ }^{1}$ khalid.2013sk@gmail.com; ${ }^{2}$ natalja.lace@ rtu.lv; ${ }^{3}$ irena.danileviciene@vgtu.lt (corresponding author)
}

Received 15 April 2020; accepted 05 May 2020

\begin{abstract}
The study evaluates the comparison and efficiency of Pakistani Islamic and conventional banks. Data are collected from the reports of banks website and state bank of Pakistan for the period 2013-2017. Used financial ratios for methodology and descriptive summary, correlation and Trend for analysis technique. The analysis shows conventional banks are more liquid, solvent and less risky. According to profitability ratio, Islamic banks are more profitable. Trend analysis shows, both banks have positive trends, but the conventional banks disclose more efficiency and positive trend. Conventional banks are technologically advanced and extensive, but the future of Islamic banks looking bright in case of Pakistan.
\end{abstract}

Keywords: bank, conventional banks, Islamic banks, return on assets, return on equity.

JEL Classification: E21, F38, G21.

\section{Introduction}

Today Pakistan banking division assuming a cardinal job in the advancement of the nation's economy and banking sector as well. Pakistan banking framework consists of a total of 46 banks according to the latest data, which is 09 March 2019. The central bank of Pakistan is the state bank of Pakistan, and five big size banking is operating in Pakistan, namely Allied Bank, Habib Bank, MCB Bank, National bank and UBL bank. There are 17 Commercials or conventional Banks that are further divided into the public and private sector, 6 are pure Islamic banks, 6 are microfinance banks, 5 are the foreign banks and 7 are the defunct banks as well. The banking system plays a significant role in boosting the economy and provide investment opportunities like banks received the deposit from different sources and then made loans on demand, which is very important to keep the economy stable.

Islamic and conventional banks are working for giving monetary middle person job. Money related go-between implies that banks are working for two sorts of clients. First are the individuals who need cash to meet their consumption because their uses are higher than their salary. That is the reason they need more cash fit as a fiddle of further capital or obtaining. Banks give grants of loaning to clients addressing their needs effectively without affecting the activities of the business. The other sort of client has pay higher than their consumptions. Along these lines, they have surplus cash after meeting their uses and those store surplus cash in banks. Banks utilize this surplus cash for loaning reason to give it to clients, who have higher applications than pay for satisfying their needs. In this way, banks are functioning as a delegate and take a commission from obtaining clients and pay to store clients as indicated by their bundles and give a lot of progressively money-related functions.

An interest-free financial framework is wholly founded on Islamic guidelines and its financial activities are performed as per Islamic standards and its practical use was proceeded by making Islamic monetary framework. In 1940 Islamic banks escalated their development and turned into another adversary in the banking area. Islamic banking arrived at its pinnacle level and extended in all Muslim and non-Muslims nations. Islamic banks turned into an option for the economy and a greater part of countries were adjusting to Islamic banking.

Inside not many decades, the Islamic economy idea quickly advanced in four landmasses likes Asia, Africa, Europe, and North America. Around 300 monetary organizations are filling in as Islamic banks in 70 nations of the world and their ven- 
ture came to up to $\$ 500$ Billion to $\$ 800$ Billion. In the late period, Islamic banks have $\$ 4$ trillion in market esteem. In Arab nations, this idea has become a prevalent financial idea. Bahrain is from those nations who quickly embraced the Islamic monetary framework and Malaysia is on second due to its magnificent approaches concerning Islamic banking.

All the parties relating to the banks like customers, bank staff, investor and regulators. One thing is essential to evaluate the performance of the bank. In nowadays, like competing for situations whenever depositing or withdrawing money, the important thing is to check the banks' performance, which gives the signal whether it's good for investor/depositor or not. The manager plays a significant role in improving the service of deposit and they know very well and take management decisions according to the situation. On the other hand, regulators are also responsible for building positive trust with the customer and keeping the banks safe and check the performance of banks. Compare the banks with those banks which are already in problems is very important, sometimes a small issue does not take seriously, and it's led a bank to bankruptcy (Hassan \& Bashir, 2003; Samad \& Hassan, 2000).

Conventional banking or interest-based banks are entirely founded on the monetary model, which pursues the industrialist economy. In this framework, banks mostly acquire from Savers who have surplus cash and loan to ventures or people who need money for addressing their needs. In interestbased banks, the benefits of banks are interest spread, which is a distinction among enthusiasm winning and premium costs. In this framework, banks likewise gain income from free sources by giving administrations to global exchanging, for example, letter of credit and letter of assurance. In these exchanges, they function as brokers among exporters and shippers and get a commission.

The banking industry advances sparing and speculation exercises for the development of business and exchange exercises nation. Pakistani financial division had encountered most exceedingly terrible changes in six many years of its life. The beginning of Islamic banking made a focused situation for the banking part, particularly for ordinary banks because of its fast development in Pakistan. This examination will research the administration nature of banks and their impact on the capability of premium based and premium free preparing.

Research issue centred in this study is, there are not many researchers conducted on both types of banks. Namely, Islamic banks and conventional banks and not concentrated on various sorts of methodology at once, yet most centred was around conventional banks. However, the Islamic banking industry still needs to do more and more research work. Another issue centred in this study is that not many studies are conducted to measure the efficiency of the banks in Pakistan since 2013 and not selected the banks. As a sample which starts their activities after 2010, and not utilizing a wide range of banks (private, public, domestic, foreign, multinational). Since Islamic banking is in the initial stage in Pakistan, so there is a substantial need to direct execution assessment, which is likewise significant for the policymaker, upper-level management, employee, customers, investors, managers and regulators speculators. All these need securities against the safe care of monetary resources, so it's essential to think about the money related execution investigation of conventional and Islamic banks to follow the right direction and choose the correct choice.

\section{Research questions}

- Which of the banking system is relatively more efficient?

- What are the elements of efficiency to achieve?

- Is it true that the Islamic banking system and new regulations implemented by the Pakistan government in the banking sector, create more competition among the banks?

- Which of the banking system is more profitable?

\section{Objectives of the study}

The following are the primary purposes of this research: to describe the concept of Islamic banking performance comparison of Islamic and conventional banks operating in Pakistan, to measure the performance efficiency and growth of Pakistan's banking sector.

\section{Literature review}

While there has been extensive literature examining the efficiency features of the contemporary banking sector, particularly the work on US and European banking markets and similarly in the rest of the world but work on Islamic banking is still in its infancy. However, this type of research is gradually changing as several recent studies have sought to apply various techniques to estimate the efficiency of Islamic and Conventional based banking (El-Gamal \& Inanoglu, 2003).

The foundation of a sound financial system is always built on an underlying theoretical frame- 
work. Both Islamic and conventional banks have their distinctions. The conventional banks are based on the principles of a positive theory of economics, while Islamic banks are based on the principles of the sharia of Islam.

The banking industry plays a vital role in the boosting of the economy of any nation is principal and banks' execution has been eminent since the past and they ought to keep up their solidness. Estimating the productivity of banks is a method that is utilized by banks to gauge the achievements of banks. There are numerous approaches to quantify productivity; however, usually used is PMS; how to amplify yield from least info and proficiency subsequently is estimated by minimization of cost. Specialists have utilized various procedures for examinations of how banks raise their efficiencies. As indicated by Kumar and Gulati's (2010) factors used to discover the proficiency are staff efficien$\mathrm{cy}$, size, and piece of the overall industry.

Sheikhothman and Faheds (2009) studied how the assets and liabilities of the conventional and Islamic banking sector can be managed. Profitability and liquidity were chosen as factors. The study sample included equally both types of banks from Jordan for the period from 2000 to 2008. All the data were collected from the secondary sources and each annual bank report. The author used different techniques for analysis, namely the regression, correlation and descriptive analysis. The result finds out that there is a direct relationship between assets and liabilities of both banks on ROE ratio and Islamic banks are found low risky in the context of assets and liabilities as compared to the conventional banks.

Hassan et al. (2009) and Said et al. (2013) researched conventional and Islamic banks to measure efficiency. The purpose of the research is to present the different efficiency levels of revenue, cost and profit of Islamic and conventional banks. 40 banks of Islamic countries were chosen as a sample for the study for the sample period of 1999 to 2005 . All the data were collected from the annual reports. The overall result interpreted that there are no such differences in the efficiencies of both bank's conventional and Islamic banks. But on average, the result in the Islamic banking system is performed and managed their resources in a better way to generate more profit, but there is no such difference occurs based on size and age.

Jaffar and Manarvi (2011) researched both types of banking systems to measure their efficiency. They used the CAMEL model to measure the performance of Islamic and conventional banks. They have chosen five banks from each bank and the sample period was five years as well. CAMEL model gives the result that Islamic banks are better than non-Islamic banks based on management and earning mean Islamic banks performing better in terms of management and they received more than conventional banks. They also point out that both types of banks are much similar in terms of profitability and liquidity analysis.

Sufian and Noor (2009) looked at by considering MENA and Asian Islamic banks to assess their specialized, unadulterated and scale proficiency by utilizing the Data Envelopment Analysis system. The outcome uncovers that MENA Islamic banks had higher usual specialized skills in contrast with their Asian partners. A positive critical relationship of skilled effectiveness has been found with productivity, size, capitalization, credit power and specialized wastefulness. It is recommended to improve the administrative abilities for more proficiency upgrade of Islamic banks.

Hamid and Azmi (2011) conducted a study on the Islamic banking system and conventional banking system to measure the efficiencies of both banking types. The sample period for the study was chosen from 2000-2009. They used financial ratios in the research and ran a t-test to measure the performance of both banks. After running the test, they concluded that Islamic banks are performing better in terms of liquidity, profitability, and solvency.

Imam and Kpodar (2010) did research the purpose behind this study is to find out the factors which are helpful in the expansion of the Islamic banking system all over the world. The study has chosen the different types of variables that alter the development of the Islamic banking system, namely the Muslim population, income per person, interest rate, $9 / 11$ event, oil prices, the consolidation with middle east countries, the distance from the Bahrain and Malaysia as well. The result has demonstrated that the average income is the direct relationship to the spreading of Islamic banks and banking system competition is also playing a decisive role in the spreading od Islamic banks.

Usman et al. (2010) expressed by applying DEA procedure over a board of regular banks of Pakistan to look outside. The state claimed and local private banks. It has been discovered that foreign requested banks are progressively effective in terms of specialized proficiency while country possessed, and private household banks are seen as the least proficient banks. Beneficial productivity is additionally isolated into Technical and Allocative effectiveness. This exploration study was expected to assess the productivity of Conventional Pakistan 
banks from 2001-2008. It has been deduced in this examination that there is having to accomplish something for the improvement of state possessed and local private banks to upgrade their specialized productivity.

Kosmidou et al. (2005) predicted the performance of cooperative and conventional banks. The sample for the study they took was 14 conventional banks and 16 are cooperative banks. He divides the banks into two groups, big and small, which depend on total assets. They used the CAMEL approach to evaluate the performance of each bank and the plan contains different ratios, namely equity to assets, loan to assets and earning before capital and total assets and utilized various tests in his appraisal. The outcome shows that the conventional banking system is more favourable in increasing their market share.

Said (2012) examined the effectiveness of Islamic banks utilizing DEA and the t-test to check hypotheses and the period is chosen in the range of 2006 and 2009. The result demonstrates that the proficiency of Islamic banks in Middle Eastern and non-Middle Eastern nations expanded during the financial emergency. Besides this, the profitability of bigger Islamic banks grew during the period from 2006 to 2008 and diminished in 2009. Then again, the small and medium Islamic banks in the investigation had lower proficiency levels than those of the large banks.

Canhoto and Dermine (2000) explore the proficiency of Portuguese banks for the time of 1990-1995. They utilized a non-parametric programming procedure, Data Envelopment Analysis (DEA) (Khezrimotlagh et al., 2019) model to evaluate the productivity of 20 banks. Banks were separated into portions of an old Commercial bank, Old reserve funds banks and new banks. The outcomes demonstrate that over the period, mechanical changes, as determined by the DEA model, indicate that productivity of new banks is ascended by $59 \%$ when contrasted with the old financial framework.

Another study, conducted by Onour and Abdalla (2010), and used the DEA technique. The objective of the study was to measure the scale and technical efficiency and select the twelve banks of Sudan and the period was from 2007 to 2008 . They have chosen three inputs and two outputs variables, salary and wage expenses and total deposits as input variables and total loans and net income as the outputs. After applying the DEA, the result shows that all the more substantial size banks and one average size bank were pure and scale efficiently. Still, small banks in size were only absolute technical profitable but not scale efficiently.
Yahya et al. (2012) and Mokhtar et al. (2008) looked at the proficiency of Islamic banks and conventional banks in Malaysia. They presumed that the efficiency of the Islamic banks was practically equal to that of the conventional banks, despite the way that they were constrained by the directs of Sharia standard. Mokhtar et al. (2008) looked at the proficiency of "pure Islamic banks" and the "Islamic windows of regular banks." The consequences of the investigation show that even though the "pure Islamic banks" were more effective than the "Islamic windows," on the other hand, pure Islamic banks were less proficient than the commercial banks in Malaysia.

Javed et al. (2015) researched to check the financial performance of conventional and Islamic banks in evidence of Pakistan and Malaysia, the sample period for the study was 2008 to 2012, all the data were collected from the annual report of each official bank website. The author used the approach which based on observation and theories and gathers some indicator through which they check the performance of the asset. The result shows that the equity rate of return is growing continuously, which points out that Islamic banks adopt the equity maximization strategy. But the solvency ratio for Islamic banks in the case of assets and deposits does not show the maximum rates.

Arslan and Ergec (2010) done a research study in turkey on Islamic bank's conventional banks. They have chosen 26 interest-based banks and all the Islamic banks that are functional at that time. Therefore, their examinations between the interest-based banks and Islamic banks are available to address since, before 2006, the Islamic banks had not been exposed to the same guidelines from conventional banks. Then again, the investigation shows that after the instructions were executed, there was a critical improvement in 2009 in the productivity of the Islamic banks.

Al-Khasawneh et al. (2012) chose the north African country's banks for measuring efficiency, whether they are efficient or not? They also apply the DEA method as an approach. Three inputs are selected, namely fixed assets, loanable funds and personnel expenses and two output net loans and other earning assets. The observational outcomes show that the Islamic bank's revenue efficiency growth was less than as compared to interest-based banks because Islamic banks are in the emerging stage in African countries. 


\section{Methodology}

Data for this research is collected from secondary sources such as the websites of Karachi Stock Exchange (KSE), State Bank of Pakistan (SBP) and concerned banks official sites for five years from 2013 to2017. All the data are in Pakistan's currency (rupees). The secondary data is beneficial while testing the hypothesis. These five years were selected because, during this period, the banking sector passed through the worst economic conditions in Pakistan, especially the Islamic banking system, because of in developing stage. Five Islamic banks (Table 1) and five conventional banks were selected as a sample from the banking sector of Pakistan. All these banks are well known, listed at KSE and have a significant market share. For analysis of data collected from the above-mentioned sources, descriptive statistics, correlation and regression analysis are applied as Statistical techniques and all the report runs in software name R-studio and excel.

Table 1. Pakistan Islamic and conventional banks

\begin{tabular}{|c|l|l|}
\hline No & \multicolumn{1}{|c|}{ Islamic Banks } & \multicolumn{1}{|c|}{ Conventional Banks } \\
\hline 1 & Meezan Bank & United Bank Limited \\
\hline 2 & Dubai Islamic Bank & $\begin{array}{l}\text { Muslim Commercial } \\
\text { Bank }\end{array}$ \\
\hline 3 & Bank Islamic & Allied Bank \\
\hline 4 & Al Baraka bank & Habib Bank Limited \\
\hline 5 & Bank Alfalah & Faysal Bank Limited \\
\hline
\end{tabular}

\section{Descriptive statistics}

A descriptive statistic is a data analysis tool that explains the expressive technique of giving data, which can explain the whole date for the selected sample. Descriptive statistics calculate the central tendency, which contains mean, standard deviation, min, max, standard error, median, mode, kurtosis, skewness and standard error.

\section{Correlation analysis}

A correlation coefficient is also a tool for data analysis that measures the relationship between two variables. It shows us if one variable is changing the what effect will occur on other viable whether it will be positive or negative. Why we need to understand this relationship because when we can apply the value of one element to predict the amount of another item. If its fall in between -1 to +1 its shows the relationship.

\section{Financial ratios}

Capital Adequacy Ratio (CAR) is an indicator that measures the strength of a bank's capital. It shows the risk weight of credit exposure. CAR ratio is beneficial for checking the money of financial institutions. CAR calculated by the formula (1):

\section{$C A R=$ Tier 1 Capital + Tier 2 Capital $/$ Risk Weighted Assets.}

Return on Equity (ROE) ratio is used to measure the performance of the total capital of a company. ROE is calculated by using the firm's net profit and total equity finance. ROE is shown in percentage. ROE calculated by the formula (2)

$R O E=($ Net profit $/$ Total Assets $) \times 100$.

Deposits to Total Assets Ratio (DTAR) DTAR shows the credit standing of the bank by considering the relationship between deposits and total assets of banks.

DTAR $=($ Total Deposit $/$ Total Assets $) \times 100$.

Advances Turnover Ratio (ATR) represent how much interest is earned from the total progress of the bank. It is a useful measure to check the efficiency of bank performance.

ATR $=($ Total Sales $/$ Total Advances $) \times 100$.

Net spread ratio (NSR) is used to measure the net interest income earned by a bank. This ratio represents the primary income of banks.

$N S R=$ Interest Income - Interest Expenses.

Return on Assets (ROA). ROA is a performance indicator that is used to measure the efficiency of the total assets of a company. ROA is obtained with the use of total average assets of the bank and net profit after tax, ROA is shown as a percentage. Sometimes it's written as an investment in total assets of the bank.

ROA $=($ Net Profit $/$ Total Assets $) \times 100$.

\section{Trend analysis}

In this study, Trend analysis means to examine the financial data of the chosen banks. The reason behind the trend analysis is to check the efficiency of each banking system, whether it is moving in the right direction or not. Trend analysis can also predict the future condition of the indicators on the recent trend data, namely Total assets, total liabilities, net assets, share capital reserves, gross income, total expenses and profit before and aftertax. 


\section{Hypothesis}

H1: Islamic banks are more profitable than conventional banks.

H2: Islamic banks are highly liquid than Conventional banking.

\section{Empirical analysis, results and discussions}

This segment explains the statistical results of variables related to the study. This section consists of group statistics, correlation and regression analysis of variables and theoretical discussion on outcomes of these tests.

\subsection{Descriptive statistics}

Tables 2 and 3 are used to describe the 5 years summary of statistical analysis for Islamic and non-Islamic banks. In conventional and Islamic bank's mean, the median and standard deviation of the dependent variable ROA is $1.6216,0.6720$, $1.6380,0.6640$ and $1.0 .5963,0.3641$, respectively. Return on assets of Conventional banks is better and more consistent than Islamic banks.

Table 2. Descriptive statistics of conventional banks 2013-2017 (source: compiled by the authors, based on own calculations)

\begin{tabular}{|l|c|c|c|c|c|c|}
\hline & $R O A$ & $R O E$ & $C A R$ & $A T R$ & NSR & DTAR \\
\hline Mean & 1.6216 & 19.5280 & 16.8120 & 86.1380 & 46.6080 & 75.3540 \\
\hline Standard Error & 0.2667 & 1.9999 & 1.3407 & 68.1326 & 5.4857 & 0.7177 \\
\hline Median & 1.6380 & 21.3400 & 16.0200 & 19.2300 & 46.3300 & 75.3100 \\
\hline Standard Deviation & 0.5963 & 4.4720 & 2.9980 & 15.2349 & 12.2664 & 1.6048 \\
\hline Kurtosis & 0.0366 & -2.4880 & -2.7659 & 4.9914 & 0.6610 & -2.0593 \\
\hline Skewness & 0.0799 & -0.5851 & 0.3137 & 2.2337 & -0.8380 & 0.1630 \\
\hline Range & 1.5900 & 9.7900 & 6.6500 & 343.5600 & 31.7200 & 3.8100 \\
\hline Minimum & 0.8400 & 13.7300 & 13.6800 & 15.0500 & 27.9000 & 73.5600 \\
\hline Maximum & 2.4300 & 23.5200 & 20.3300 & 358.6100 & 59.6200 & 77.3700 \\
\hline Sum & 8.1080 & 97.6400 & 84.0600 & 430.6900 & 233.0400 & 376.7700 \\
\hline Count & 5 & 5 & 5 & 5 & 5 & 5 \\
\hline
\end{tabular}

Table 3. Descriptive statistics of Islamic Banks 2013-2017 (source: compiled by the authors, based on own calculations)

\begin{tabular}{|l|c|c|c|c|c|c|}
\hline & $R O A$ & $R O E$ & $C A R$ & $A T R$ & NSR & DTAR \\
\hline Mean & 0.6720 & 13.8680 & 12.9585 & 24.4770 & 44.8750 & 82.4955 \\
\hline Standard Error & 0.1821 & 3.6627 & 0.5518 & 8.6530 & 2.8374 & 2.7980 \\
\hline Median & 0.6640 & 14.5910 & 12.6130 & 16.7790 & 44.3540 & 84.0170 \\
\hline S. Deviation & 0.3641 & 7.3253 & 1.1036 & 17.3060 & 5.6748 & 5.5959 \\
\hline Sample Variance & 0.1326 & 53.6603 & 1.2180 & 299.4964 & 32.2031 & 31.3141 \\
\hline Kurtosis & -3.8725 & -1.5538 & 1.1575 & 3.8897 & 1.0786 & 0.1957 \\
\hline Skewness & 0.0699 & -0.4358 & 1.3281 & 1.9644 & 0.5224 & -1.1192 \\
\hline Range & 0.7800 & 16.6540 & 2.4000 & 36.3700 & 13.6800 & 12.2120 \\
\hline Minimum & 0.2900 & 4.8180 & 12.1040 & 13.9900 & 38.5560 & 74.8680 \\
\hline Maximum & 1.0700 & 21.4720 & 14.5040 & 50.3600 & 52.2360 & 87.0800 \\
\hline Sum & 2.6880 & 55.4720 & 51.8340 & 97.9080 & 179.5000 & 329.9820 \\
\hline Count & 4 & 4 & 4 & 4 & 4 & 4 \\
\hline
\end{tabular}


In conventional banks, Islamic ROE, CAR, ATR, NSR and DTAR are independent variables and their means are $19.5280,13.8680,16.8120$, $12.9585,86.1380,24.4770,46.6080,44.8750$ and $75.3540,82.4955$ respectively. In the case of Islamic banks, the Mean of independent variable DTAR is higher than in conventional banks, but ROE, CAR, ATR and NSR are lower than in conventional banks.

Standard deviation of ROE, CAR, ATR, NSR, and DTAR (independent variables) for interest-free and interest base banks are 4.4720, 7.3253, 2.9980, $1.1036,15.2349,17.3060,12.2664,5.6748$ and $1.6048,5.5959$ respectively. Islamic bank's SD is higher as compare to conventional banks, which shows that Islamic banks are performing well than interest-based banks. Minor fluctuations in standard deviation occur that Islamic banks are more consistent than conventional banks.

\subsection{Correlation analysis}

Figure 1 and 2 and Table 4 and 5 represents the correlation matrix of the independent variables for Islamic and conventional banks. Correlation analysis is a statistical technique that is used to check the Multi co-linearity among independent variables. When Correlation is positive, then values will move in the same direction, but when they walk in the opposite direction, correlation is negative.

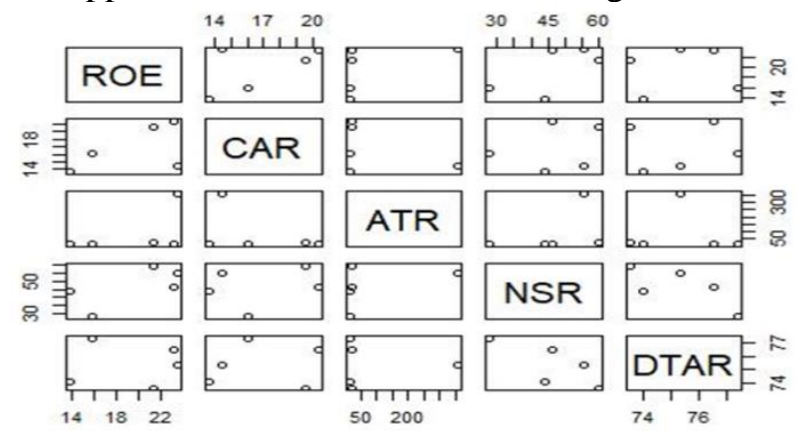

Figure 1. Correlation analysis of conventional banks 2013-2017 (source: compiled by the authors, based on own calculations)

Table 4. Correlation analysis of conventional banks 2013-2017 (source: compiled by the authors, based on individual estimates)

\begin{tabular}{|l|c|c|c|c|c|}
\hline & ROE & CAR & ATR & NSR & DTAR \\
\hline ROE & 1 & & & & \\
\hline CAR & 0.552734 & 1 & & & \\
\hline ATR & 0.51372 & -0.42298 & 1 & & \\
\hline NSR & 0.646295 & 0.256832 & 0.411586 & 1 & \\
\hline DTAR & 0.032743 & 0.086821 & -0.02467 & -0.73927 & 1 \\
\hline
\end{tabular}

Islamic banks' ROE has a positive relation with NSR\&ATR but a negative association with CAR \& DTAR. Conventional banks' ROE is having a favourable relationship with CAR, ATR and NSR \& DTAR. Islamic banks' CAR is negatively correlated with all variables except DTAR. Conventional banks' CAR is found to have a positive dependence on NSR and DTAR. ATR is adversely associated.

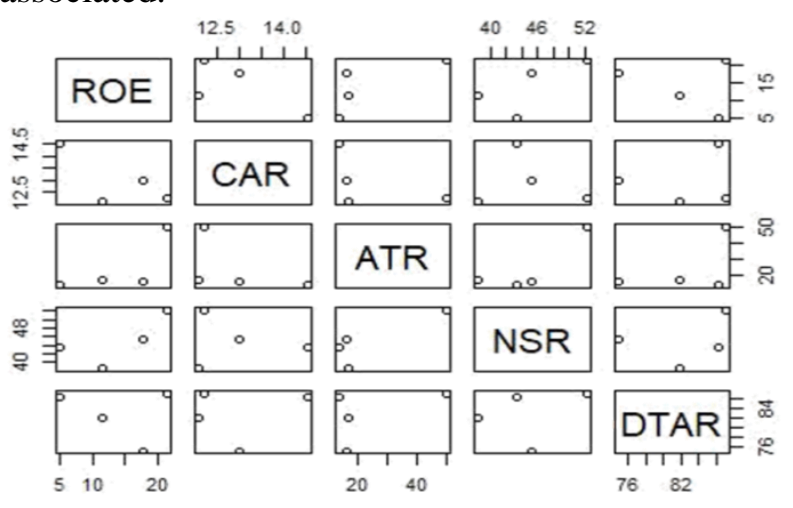

Figure 2. Correlation analysis of Islamic banks 2013-2017 (source: compiled by the authors, based on own calculations)

Table 5. Correlation analysis of Islamic banks 2013-2017 (source: compiled by the authors, based on individual estimates)

\begin{tabular}{|c|c|c|c|c|c|}
\hline & ROE & CAR & ATR & NSR & DTAR \\
\hline ROE & 1 & & & & \\
\hline CAR & -0.71285 & 1 & & & \\
\hline ATR & 0.734791 & -0.50615 & 1 & & \\
\hline NSR & 0.697395 & -0.12196 & 0.849167 & 1 & \\
\hline DTAR & -0.22149 & 0.151058 & 0.497961 & 0.305373 & 1 \\
\hline
\end{tabular}

ATR of interest-free banks is positively associated with NSR \& DTAR. Still, on the other side, ATR of conventional banks has negatively related to DTAR and positively associated with NSR. Islamic banks NSR has a positive correlation with ROE \& ATR, but it is negatively associated with CAR. Conventional banks NSR has a Positive relationship with ATR, CAR and ROE.

In correlation matrix Islamic banks DTAR is positively related to NSR, ATR \& CAR and negatively related to ROE. Conventional banks DTAR having a positive relationship with all independent variables except NSR.

\subsection{Trend analysis}

Figure 3-6 shows the trend analysis of Islamic and conventional banks in Pakistan for the sample pe- 
riod of 2013 to 2017. All the data are collected from the annual report of each bank.

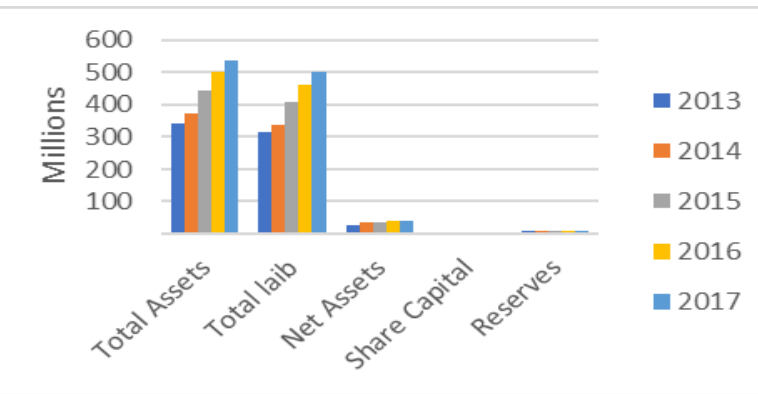

Figure 3. Trend analysis of balance sheet of conventional banks (source: compiled by the authors, based on own calculations)

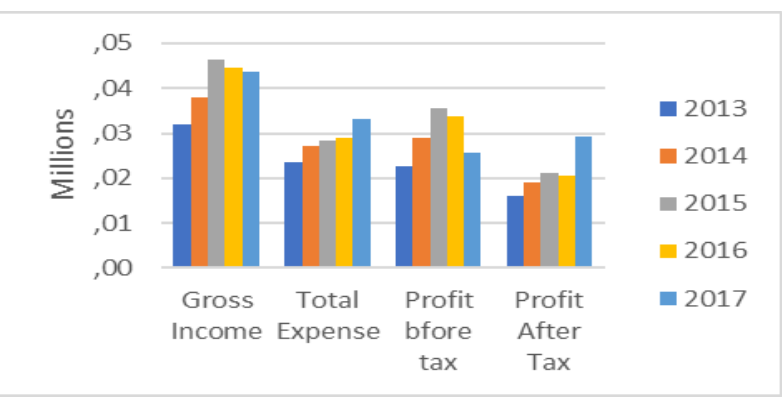

Figure 4. Trend analysis of income statement of conventional banks 2013-2017 (source: compiled by the authors, based on individual estimates)

Trend analysis of conventional banks is increasing from year to year in the context of the balance sheet, which shown in Figure 5. The result signifies that the conventional banks are still in developing stage and year by year its increasing their share in the market. While on the other hand, in the case of the income statement of conventional banks (Figure 6), the total expenses and profit are showing an upward trend, which is a good sign, but the gross income and profit before tax fluctuate from year to year (2013-2017).

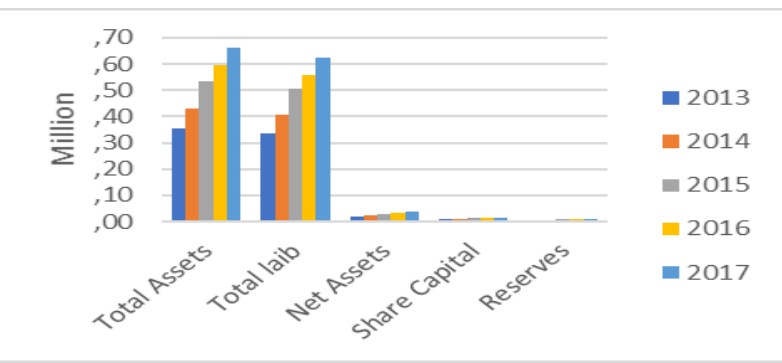

Figure 5. Trend analysis of balance sheet of Islamic banks 2013-2017 (source: compiled by the authors, based on individual estimates)

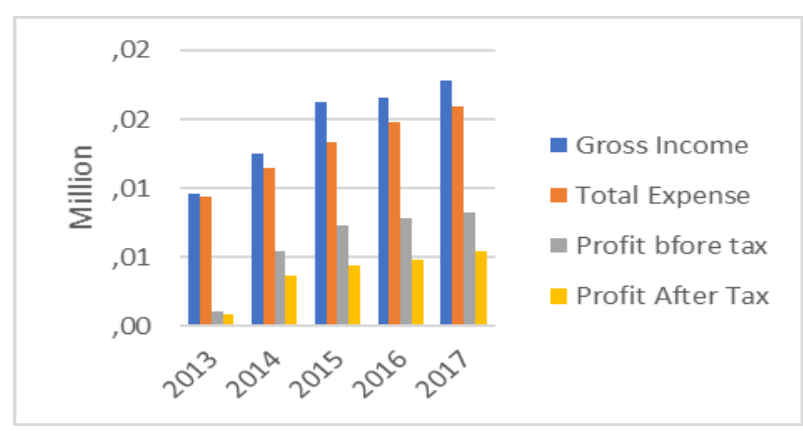

Figure 6. Trend analysis of income statement of Islamic banks 2013-2017 (source: compiled by the authors, based on individual estimates)

Trend analysis of Islamic banks shows an upward trend in the case of both balance sheet and income statement. So, there is contentious growth in the Islamic banking system. This upper trend means a positive sign for Islamic banks and shows efficiency.

\subsection{Hypothesis testing}

Table 6 shows the t-test values for testing the hypothesis and concluded the result with the help of p-value and mean whether the hypothesis is accepted or rejected.

Table 6. T-tests of financial ratios for hypothesis testing of Islamic and conventional banks (source: compiled by the authors, based on individual estimates)

\begin{tabular}{|c|c|c|c|}
\hline Banks & Ratios & Mean & $\mathrm{P}_{-}$Value \\
\hline IB & ROA & 0.67 & 0.004 \\
\hline CB & ROA & 0.62 & 0.061 \\
\hline IB & ROE & 0.16 & 0.006 \\
\hline CB & ROE & 0.14 & 0.074 \\
\hline IB & CAR & 0.13 & 0.071 \\
\hline CB & CAR & 0.17 & 0.040 \\
\hline
\end{tabular}

In the case of Islamic banks, the p-value for ROA and ROE is less than 0.05 , which shows the mean of Islamic banks is better than conventional banks and find that Islamic banks are more profitable than conventional banks and also except the hypothesis. In the case of liquidity ratio CAR, conventional banks have higher mean then Islamic banks. The hypothesis is rejected here and concludes that conventional banks are higher liquidity than Islamic banks.

\section{Conclusions}

The paper aims to find out the efficiency analysis of Islamic and conventional banking sector in Pa- 
kistan from 2013 to 2017 with the help of financial ratios and trend analysis. Conventional banks are in operation for a long time, but Islamic banks are a new experiment for the Pakistan banking system. According to the result of our study, some variables are valuable when we measure the efficiency of banking sectors.

According to the result of descriptive analysis, the ROA of conventional banks is better than Islamic banks. CAR of conventional banks is favourable than Islamic banks, which means that conventional banks are low in risk and their financing is also secured. DTAR of Islamic banks is unusual for promising customers and too good than conventional banks, so conventional banks depend on debt financing while Islamic banks rely upon equity financing. However, the overall result shows that conventional banks are growing very well in Pakistan banking systems, but the future of Islamic banks will also be bright.

The result of trend analysis shows that the profit after tax of both banks shows a positive outcome. The reason for the positive sign means both banks are working in the right direction. On the other hand, expenses also show an upward sign which can affect their profit in the future. In the rest of the trend analysis in the case of balance sheet elements, both banking systems show an upward trend from year to year. Still, in the case of the income statement, the conventional banks fluctuate from year to year. In contrast, Islamic banks show an upward trend in all income statement elements.

Future studies of the banking industry should compare efficiency scores based on a parametric approach along with a non-parametric plan to check the efficiency and consistency of both banking systems in Pakistan. Recommend choosing both type quantitative and qualitative inputs and output for a non-parametric approach. Data will also have considered, like the quality of services provided by the different banking sectors and levels of technological advancement, will also have included in the analysis. Selected input and output variables might not be in-depth, and the dataset is limited so, future studies could enhance the scope of their research by adding other variables in their research. Also, consider a survey on changes in productivity over time due to technological development or technological progress. This study may further perform to conduct the comparative efficiency of both banks or to compare financial products and to check their impact on performance and the Sample size should increase for further study \& can also be conducted globally.

\section{References}

Al-Khasawneh, J. A., Bassedat, K., Aktan, B., \& Thapa, P. D. P. (2012). Efficiency of Islamic banks: case of North African Arab countries. Qualitative Research in Financial Markets, 4(2/3), 228-239. https://doi.org/10.1108/17554171211252547

Arslan, B. G., \& Ergec, E. H. (2010). The efficiency of participation and conventional banks in Turkey: using data envelopment analysis. International Research Journal of Finance and Economics, 57, 156-168.

Canhoto, A. M., \& Dermine, J. (2000). A nonparametric evaluation of banking efficiency in Portugal. New vs. Old Banks. https://doi.org/10.2139/ssrn.221168

El-Gamal, M., \& Inanoglu, H. (2003). Efficiencies and unobserved heterogeneity in Turkish banking: 1990-2000. (Working Paper). https://doi.org/10.2139/ssrn.331980

Hamid, M. A., \& Azmi, S. M. (2011). The performance of banking during 2000-2009: Bank Islam Malaysia Berhad and Conventional banking in Malaysia. International Journal of Economics and Management, Sciences, 1(1), 09-19.

Hassan, M. K., \& Bashir, A. H. M. (2003, December). Determinants of Islamic banking profitability. In The 10th ERF Annual Conference (Vol. 7, pp. 2-31), Morocco .

Hassan, T., Mohamad, S., \& Bader, M. K. I. (2009). Efficiency of conventional versus Islamic banks: evidence from the Middle East. International Journal of Islamic and Middle Eastern Finance and Management, 2(1), 46-65. https://doi.org/10.1108/17538390910946267

Jaffar, M., \& Manarvi, I. (2011). Performance comparison of Islamic and Conventional banks in Pakistan. Global Journal of Management and Business Research, 11(1).

Javed, A., Ullah, N., \& Malik, Q. A. (2015). Comparing the efficiency of Islamic Banks of Pakistan and Malaysia: by using the DEA approach. Research Journal of Recent Sciences, 4(6), 46-52.

Khezrimotlagh, D., Zhu, J., Cook, W. D., \& Toloo, M. (2019). Data envelopment analysis and big data. European Journal of Operational Research, 271(3), 1047-1054. https://doi.org/10.1016/j.ejor.2018.10.044

Kosmidou, K., Tanna, S., \& Pasiouras, F. (2005, September). Determinants of profitability of domestic UK commercial banks: panel evidence from the period 1995-2002. In Money Macro and Finance (MMF) Research Group Conference (Vol. 45, pp. 1-27).

Kpodar, K., \& Imam, P. A. (2010). Islamic banking: how has it diffused? (IMF Working Papers, pp. 1-29).

Kumar, S., \& Gulati, R. (2010). Measuring efficiency, effectiveness and performance of Indian public 
sector banks. International Journal of Productivity and Performance Management, 59(1), 51-75. https://doi.org/10.1108/17410401011006112

Mokhtar, H. S. A., Abdullah, N., \& Alhabshi, S. M. (2008). Efficiency and competition of Islamic banking in Malaysia. Humanomics, 24(1), 28-48. https://doi.org/10.1108/08288660810851450

Onour, I., \& Abdalla, A. (2010). Scale and technical efficiency of Islamic banks in Sudan: data envelopment analysis (MPRA Paper No. 29885). https://mpra.ub.uni-muenchen.de/29885/1/MPRA_ paper_29885.pdf

Samad, A., \& Hassan, M. K. (2000). The performance of Malaysian Islamic bank during 1984-1997: an exploratory study. Thoughts on Economics, 10(1-2), 7-26.

Said, A. (2012). Efficiency in Islamic banking during a financial crisis-an empirical analysis of forty-seven banks. Journal of Applied Finance \& Banking, 2(3), 163-197.

Said, J., Ismail, F., Majid, M. Sh. A., \& Rahim, R. A. (2013). Efficiency of Islamic and conventional banks in Malaysia. Journal of Financial Reporting and Accounting, 11(1), 92-107.

https://doi.org/10.1108/JFRA-03-2013-0011
Sheikhothman, M., \& Fahad, M. (2009). Management of assets to liabilities of traditional banks and Islamic banks (Working Papers). Arabic Academy for banking and financial Sciences, Damascus, Syrian Arabic Republic.

Sufian, F., \& Noor, M. A. N. M. (2009). The determinants of Islamic bank' efficiency changes. International Journal of Islamic and Middle Eastern Finance and Management, 2(2), 120-138. https://doi.org/10.1108/17538390910965149

Usman, M., Wang, Z., Mahmood, F., \& Shahid, H. (2010). Scale efficiency in the banking sector of Pakistan. International Journal of Business and Management, 5(4), 104. https://doi.org/10.5539/ijbm.v5n4p104

Yahya, M. H., Muhammad, J., \& Hadi, A. R. A. (2012). A comparative study on the level of efficiency between Islamic and conventional banking systems in Malaysia. International Journal of Islamic and Middle Eastern Finance and Management, 5(1), 48-62.

https://doi.org/10.1108/17538391211216820 